\title{
TITLE:
}

\section{Life cycle of Bougainvillia bitentaculata (Hydrozoa: Anthomedusae) in Japan}

AUTHOR(S):

Kubota, Shin; Horita, Takushi

\section{CITATION:}

Kubota, Shin ...[et al]. Life cycle of Bougainvillia bitentaculata (Hydrozoa: Anthomedusae) in Japan. PUBLICATIONS OF THE SETO MARINE BIOLOGICAL LABORATORY 1995, 36(5-6): 351-363

ISSUE DATE:

1995-07-31

URL:

http://hdl.handle.net/2433/176245

RIGHT: 


\title{
Life cycle of Bougainvillia bitentaculata (Hydrozoa: Anthomedusae) in Japan
}

\author{
Shin Kubota \\ Seto Marine Biological Laboratory, Kyoto University, \\ Shirahama, Wakayama 649-22, Japan \\ and \\ TAKUShI Horita \\ Toba Aquarium, Toba, Mie 517, Japan
}

With Text-figures $1-8$ and Tables $1-7$

\begin{abstract}
The life cycle of Bougainvillia bitentaculata in Japan is described. The morphology and the cnidome of the hydroid and the 1-day-old immature medusa are described together with egg size, spawning time, and seasonal occurrence of medusa for the first time. A marked morphological change appeared in the laboratory-reared medusae of both sexes, especially in the number of tentacles, i.e. up to eight marginal tentacles are produced in a tentacular bulb and one of the four oral tentacles branched up to five times. As described previously, usually two marginal tentacles are present in a tentacular bulb of the medusa collected in the sea, but sometimes three and rarely four tentacles were also observed during the present study.
\end{abstract}

\section{Introduction}

Bougainvillia bitentaculata Uchida, 1925 is regarded as a rare hydromedusa in Japanese waters (Yamazi, 1958; Kubota \& Yamada, 1982), and the hydroid of this species had never been described. During the period from 1983 to 1993, however, we collected a hydroid colony and many medusae of this species from the sea, and a study on their life cycle was undertaken in the laboratory. Furthermore, egg diameter, spawning time, and the morphology and the cnidome of the hydroid and the 1-day-old medusa were examined for the first time together with the seasonal occurrence of medusa.

Kubota \& Yamada (1982) reported marked morphological changes in a medusa of this species, particularly in the number of tentacles. However, this observation was based on a single male medusa reared in the laboratory. Therefore, in the present study, special attention was paid to such morphological changes in the laboratory-reared specimens of both sexes. The morphology of the reared specimens is compared with that of many medusae obtained from the sea.

\section{Materials and Methods}

Specimens (H: hydroid; M: medusa) were collected from the following three localities in Japan: Oshoro, Hokkaido, facing the Sea of Japan $(\mathrm{H})$; Toba, Mie Prefecture, facing the Pacific Ocean (M);

Publ. Seto Mar. Biol. Lab., 36(5/6), 351-363, 1995.

(Article 28) 
Mitsuhama, Ehime Prefecture, the Inland Sea of Japan (M). Details of collection are given in text. Specimens from each locality were reared in the laboratory in filtered seawater of constant temperature, and they were fed with newly hatched Artemia nauplii. Seawater was changed nearly every day after feeding. All figures were drawn with the aid of a drawing apparatus using specimens anesthetized with $\mathrm{MgCl}_{2}$. A specimen preserved in formalin-seawater was photographed (Fig. 8).

\section{Life Cycle}

In this section, various developmental stages are described and illustrated together with remarks.

\section{Hydroid}

One fertile colony which grew on the shell of a living gastropod Mangelia deshayesii Dunker, 1860 was collected from sandy bottom (10 $\mathrm{m}$ depth) at Oshoro on November 6, 1983. In fact, it was the first record of the hydroid of this species. However, identification of this hydroid was impossible until mature medusae were obtained by rearing.

The colony consisted of many unbranched zooids arising singly from creeping stolons growing on a small shell. The filiform tentacles, numbering usually eight, formed a single whorl around the base of the hypostome. The measurements of zooids of this colony taken soon after collection and those taken during the rearing period (at $12-15^{\circ} \mathrm{C}$ until April 27, 1984) are given in Table 1.

Under the rearing conditions the zooids grew larger. The medusa buds were borne singly on short stalks (ca. $0.06 \mathrm{~mm}$ in length) arising from the stolons. They were $0.38-0.44 \mathrm{~mm}$ in height including the stalks, and always lower than the zooids. The largest medusa bud was $0.34 \mathrm{~mm}$ in diameter, and green in color with four brownish tentacular bulbs like those of young medusae (see below).

Two kinds of nematocysts are present on the tentacles of hydroids. The dimensions of undischarged capsules, maximum length $\mathrm{x}$ maximum width in $\mu \mathrm{m}$, are as follows: Desmonemes 4.8-5.4 x 3.2-3.4 ( $\mathrm{N}=6)$; Microbasic euryteles 8.4-8.9 x 3.2 $3.6(\mathrm{~N}=7)$. The cnidome of hydroid was identical to that of the mature medusa (see Kubota and Yamada, 1982) and of the immature medusa described below.

Table 1. The number and length of tentacles and size of the zooids of Bougainvillia bitentaculata.

\begin{tabular}{lcc}
\hline & \multicolumn{2}{c}{ Maximum value: } \\
& Collected & Reared \\
\hline Number of tentacles & 11 & 13 \\
Length of tentacles (mm) & 0.69 & 0.94 \\
Height of zooids (mm) & 0.63 & 1.31 \\
Width of zooids (mm) & 0.14 & 0.24 \\
\hline
\end{tabular}




\section{Medusa}

\section{Young medusa}

The young medusa within 24 hours after its release from the aforementioned hydroid is usually wider than high (Fig. 1; Table 2). The mesogloea is thin. At the umbrellar apex, a short rounded apical projection was rarely found. Nematocysts are sparsely distributed over the exumbrellar surface. The subumbrellar surface is green in color. There is no peduncle. The manubrium is tubular. There are four short unbranched oral tentacles slightly above the mouth, each terminating in a cluster of nematocysts. Each oral tentacle consists of 10-14 cells. There are four brownish tentacular bulbs without ocelli, each bearing one tentacle. The maximum length of the marginal tentacle was $2.38 \mathrm{~mm}$.

The cnidome of the 1-day-old medusa was examined in two specimens. Two kinds of nematocysts are present and their dimensions according to the body portions are shown in Table 3.

Table 2. The number of tentacles and size of the 1-day-old medusa of Bougainvillia bitentaculata.

\begin{tabular}{llllll}
\hline & Mean $\pm \mathrm{SD}$ & \multicolumn{1}{c}{ Range } \\
\hline Number of marginal tentacles & $4 \pm 0(\mathrm{~N}=217)$ & & & \\
Number of oral tentacles & $4 \quad(\mathrm{~N}=204)$, & rarely 2 & $(\mathrm{~N}=1) \quad$ or $\quad 3 \quad(\mathrm{~N}=8)$ \\
Diameter of umbrella $(\mathrm{mm})$ & $0.79 \pm 0.09$ & $0.56-0.94$ & $(\mathrm{~N}=29)$ & \\
Height of umbrella $(\mathrm{mm})$ & $0.76 \pm 0.11$ & $0.59-0.94$ & $(\mathrm{~N}=25)$ \\
Length of manubrium $(\mathrm{mm})$ & $0.34 \pm 0.04$ & $0.31-0.44$ & $(\mathrm{~N}=11)$
\end{tabular}

Table 3. Dimensions (mean $\pm \mathrm{SD}$, range in $\mu \mathrm{m}$ ) of undischarged capsules of the nematocysts of the 1-day-old medusa of Bongainvillia bitentaculata.

\begin{tabular}{|c|c|c|c|c|c|c|}
\hline Nematocysts & Body portions & Leng & & Maximum & width & $\mathrm{N}$ \\
\hline \multirow[t]{2}{*}{ Desmonemes } & Marginal tentacles & $5.8 \pm 0.36$ & $5.4-6.9$ & $3.7 \pm 0.25$ & $3.4-4.0$ & 17 \\
\hline & Tentacular bulbs & & $4.4-4.8$ & & $2.8-3.2$ & 4 \\
\hline \multirow[t]{4}{*}{ Microbasic euryteles } & Oral tentacles & $8.7 \pm 0.27$ & $8.2-9.0$ & $3.3 \pm 0.09$ & $3.2-3.4$ & 6 \\
\hline & Mouth & $8.7 \pm 0.58$ & $8.2-9.6$ & $3.1 \pm 0.23$ & $2.6-3.2$ & 7 \\
\hline & Tentacular bulbs & & $6.2-7.4$ & & $3.4-4.0$ & 5 \\
\hline & Exumbrella & $8.5 \pm 0.44$ & $7.4-8.8$ & $4.6 \pm 0.22$ & $4.2-4.8$ & 13 \\
\hline
\end{tabular}




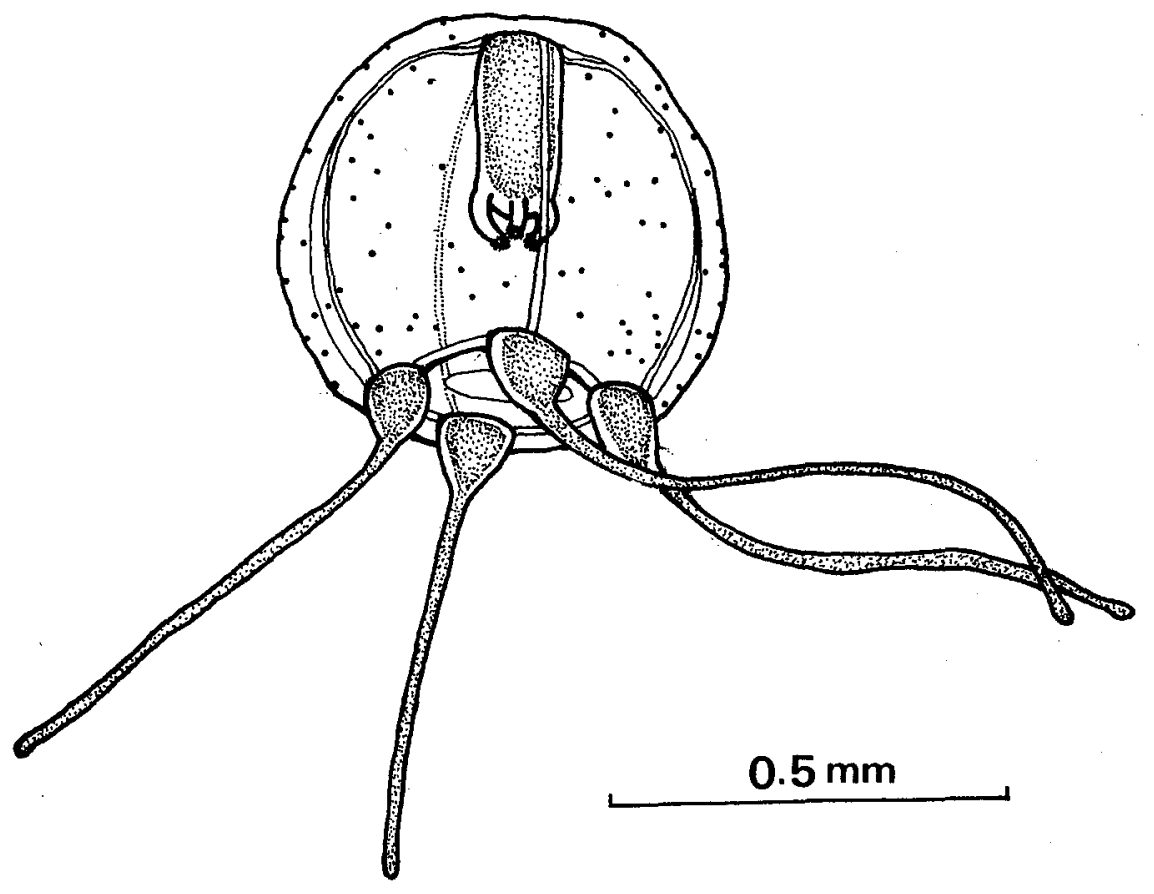

Fig. 1. A reared young medusa of Bougainvillia bitentaculata within several hours after release from the hydroid collected from Oshoro.

Immature medusa with initial peduncle

In five specimens from Oshoro, the morphology in this developmental stage was observed (Table 4). They were reared at different water temperatures after release from the hydroid. The previous data on one medusa reared for nine days after collection in the sea from the same locality (Kubota \& Yamada, 1982) is included.

Table 4. The morphology of immature medusa with initial peduncle of Bougainvillia bitentaculata reared in the laboratory.

\begin{tabular}{cccccc}
\hline $\begin{array}{l}\text { Age } \\
\text { (days) }\end{array}$ & $\begin{array}{c}\text { Diameter } \\
(\mathrm{mm})\end{array}$ & $\begin{array}{l}\text { No. of branching } \\
\text { of oral } \\
\text { tentacles }\end{array}$ & $\begin{array}{l}\text { No. of } \\
\text { marginal } \\
\text { tentacles }\end{array}$ & $\begin{array}{l}\text { No. of } \\
\text { medusae } \\
\text { examined }\end{array}$ & $\begin{array}{l}\text { Water } \\
\text { temperature } \\
\left({ }^{\circ} \mathrm{C}\right)\end{array}$ \\
\hline 7 & $1.3-1.4$ & 1 & 8 & 3 & 20 \\
$9^{*}$ & 1.2 & - & 8 & 1 & 20 \\
10 & 1.3 & 1 & 4 & 1 & 15 \\
11 & 1.2 & 1 & 4 & 1 & 12 \\
\hline
\end{tabular}

*: After Kubota \& Yamada (1982) 
When the peduncle was just produced, the umbrella was $1.2-1.4 \mathrm{~mm}$ in diameter, every oral tentacle branched once, and the total number of the marginal tentacles was up to eight (though still four at lower temperatures).

\section{Mature medusa}

Until maturation, growth of the medusa is recognized from the following points: increase of the umbrellar size together with the size of every body portion such as mesogloea, manubrium and tentacular bulbs; increase of number of marginal tentacles; branching of oral tentacles; formation of the peduncle; formation and maturation of gonads on the interradial portion of the manubrium. Medusae survived for a few months in the laboratory. They showed marked morphological changes, especially in the number of tentacles (Fig. 2). Maximally seven marginal tentacles were produced in a tentacular bulb, and one oral tentacle branched up to five times (Table 5).

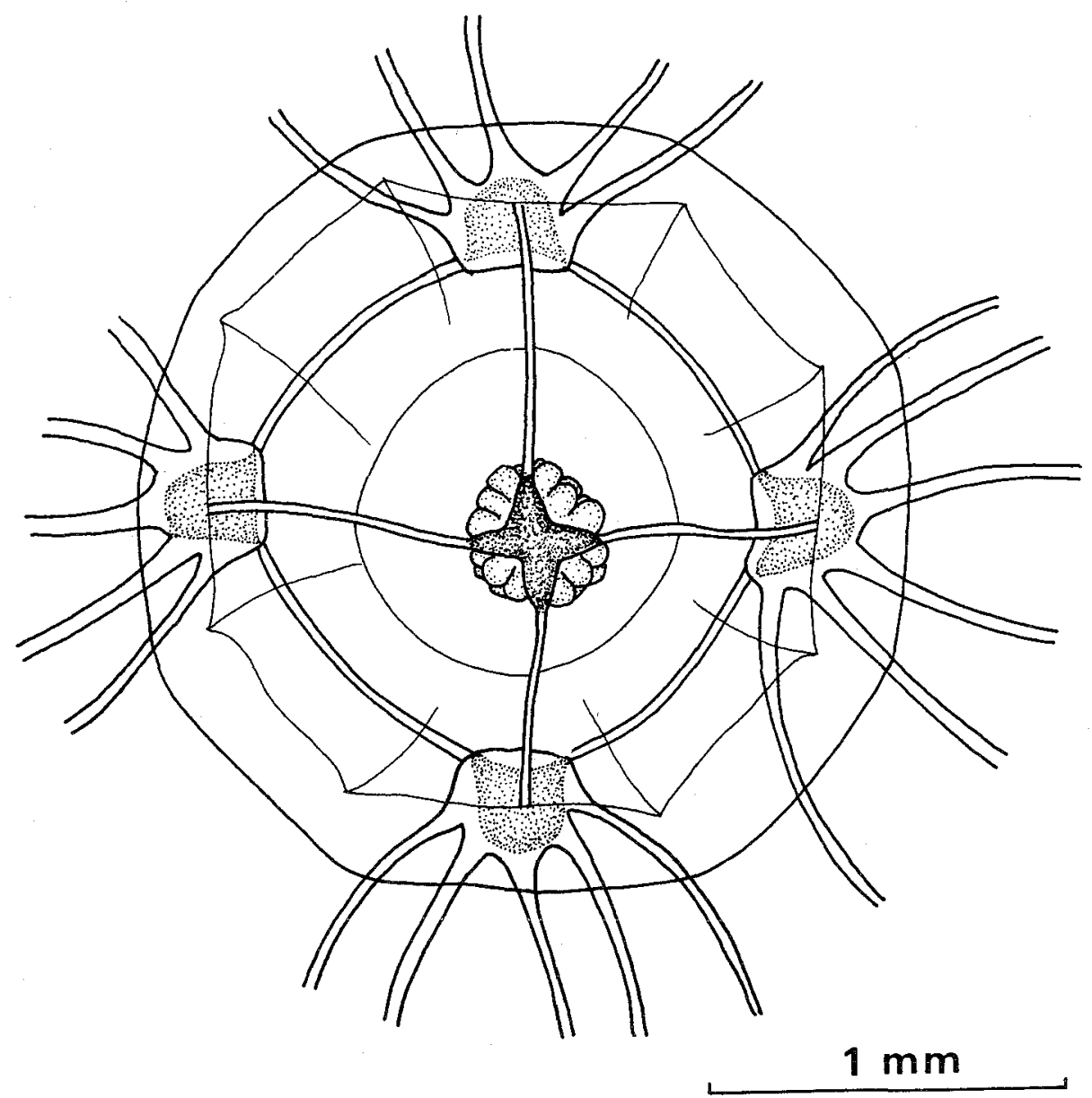

Fig. 2. A female medusa with numerous (21) marginal tentacles, reared in the laboratory for 24 days after collection at Toba (Aboral view). 
Table 5. The morphology, sex and rearing conditions of mature medusa of Bougainvillia bitentaculata reared in the laboratory.

\begin{tabular}{llllll}
\hline Maximum & No. of & Maximum & Sex & Rearing period & Water \\
diameter & marginal & no. of & $(\mathrm{m}:$ & in days (date, & temperature \\
$(\mathrm{mm})$ & tentacles & branching & male; & rearing began $)$ & $\left({ }^{\circ} \mathrm{C}\right)$ \\
& on each bulb & of a oral & $\mathrm{f}:$ & & \\
& & tentacle & female $)$ & & \\
\hline
\end{tabular}

\begin{tabular}{crrrrr}
\multicolumn{2}{c}{ Specimens from Oshoro } & & & & \\
2.5 & $5,5,5,4$ & 5 & $\mathrm{~m}^{*}$ & $83(3-\mathrm{IX}-1981)$ & 20 \\
2.2 & $4,4,4,4$ & - & $\mathrm{f}^{* *}$ & $93(18-\mathrm{XI}-1983)$ & 20 \\
2.1 & $4,4,4,4$ & 2 & $\mathrm{f}^{* *}$ & $93(18-\mathrm{XI}-1983)$ & 20 \\
2.1 & $4,4,4,4$ & - & $\mathrm{f}^{* *}$ & $93(18-\mathrm{XI}-1983)$ & 20 \\
2.8 & $3,3,3,3$ & 3 & $? * *$ & $106(15-\mathrm{XI}-1983)$ & 12 \\
2.1 & $2,2,2,2$ & 2 & $? * *$ & $38(19-X I-1983)$ & 15 \\
2.1 & $3,2,3,2$ & 3 & $\mathrm{f}^{* *}$ & $78(30-\mathrm{III}-1984)$ & -
\end{tabular}

Specimens from Toba (see Fig. 2)

$\begin{array}{llllll}2.9 & 6,6,6,5 & 4 & \mathrm{f} & 53(1-\mathrm{VI}-1992) & 25-27 \\ 2.3 & 4,4,4,4 & 3 & \mathrm{~m} & 17(1-\mathrm{VI}-1992) & 25 \\ 2.2 & 7,7,6,6 & - & \mathrm{m} & 53(4-\mathrm{VI}-1992) & 18-22 \\ 1.7 & 4,4,3,3 & 3 & \mathrm{f} & 25(2-\mathrm{VII}-1992) & 20-22 \\ 2.2 & 3,3,3,3 & - & \mathrm{m} & 25(2-\mathrm{VII}-1992) & 20-22\end{array}$

Specimen from Mitsuhama (see Figs. 3-5)

3.5

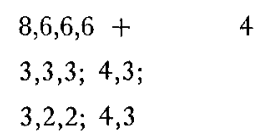

20

20

20

20

12

15

*: After Kubota \& Yamada (1982). ***: Originated from the present hydroid.

In an exceptional case, one female medusa from Mitsuhama produced much more marginal tentacles (Figs. 4, 5). This specimen was already mature when collected (Fig. 3; see Table 7). On the 21 st day of its capture, the umbrella was $2.6 \mathrm{~mm}$ in diameter, and in addition to 22 perradial marginal tentacles $(6,6,5,5$ in each quadrant), eight marginal tentacles were newly produced on four small bulbs which appeared at the interradial and the adradial portion of umbrellar margin $(3,3,1,1$ in each bulb). Increase in the number of marginal tentacles had nearly stopped since the 35 th day of capture (55-56 tentacles were found), parallel with no marked increase in the umbrellar size $(3.1-3.5 \mathrm{~mm}$ in diameter).

\section{Seasonal Occurrence of Medusa}

Seasonal occurrence of medusa of this species was surveyed at Toba from January 1991 to May 1993. Sampling of medusae was carried out at least twice in a 


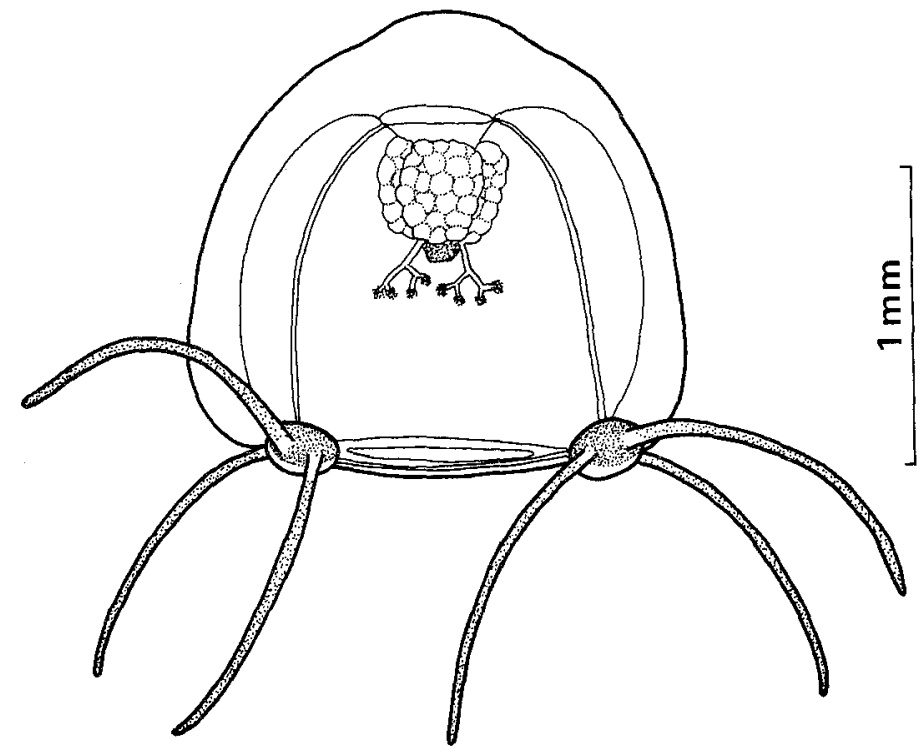

Fig. 3. A female medusa reared in the laboratory for six days after collection in the sea at Mitsuhama. One side was not drawn.

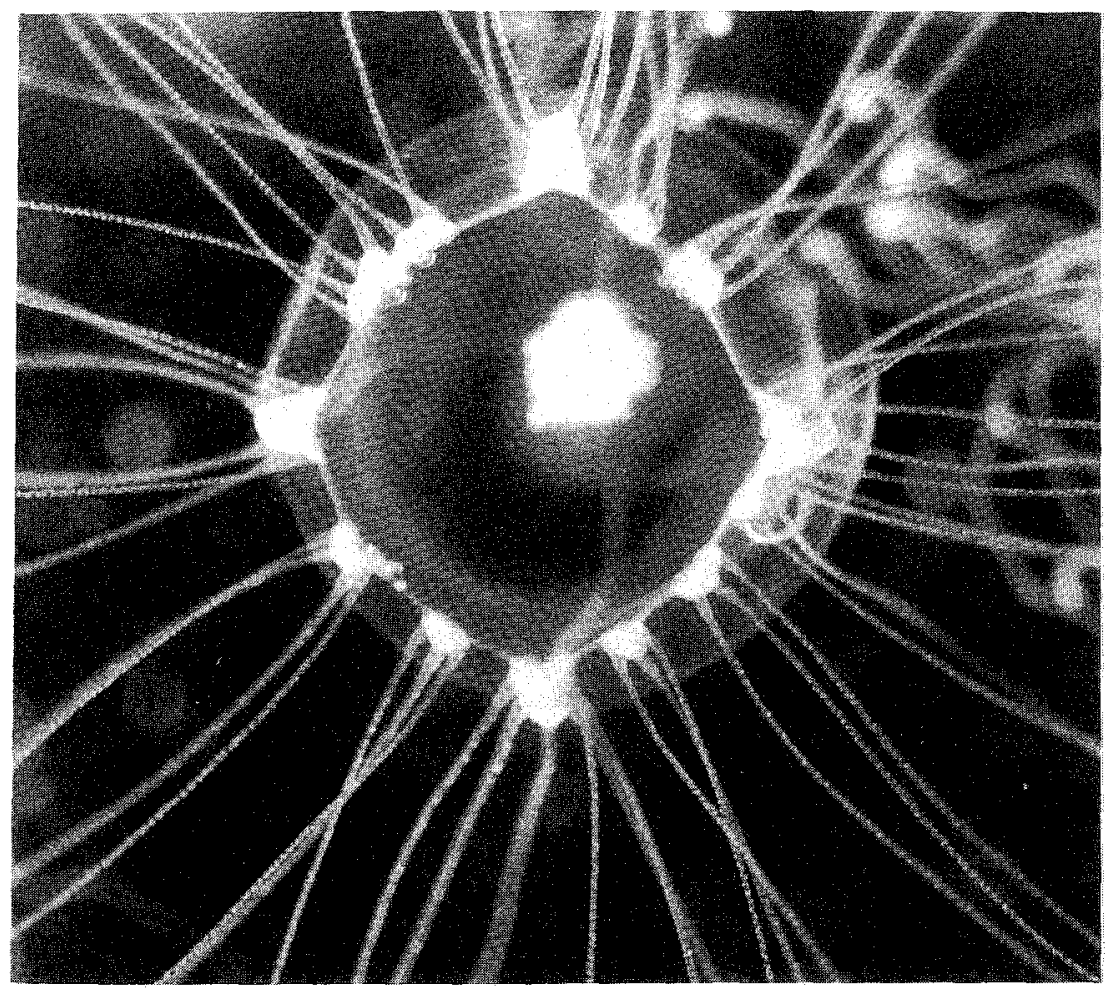

Fig. 4. An extraordinarily grown female medusa reared in the laboratory for 35 days after collection in the sea at Mitsuhama (Oral view). The umbrella is $3.1 \mathrm{~mm}$ in diameter and a total of 56 marginal tentacles are present. 


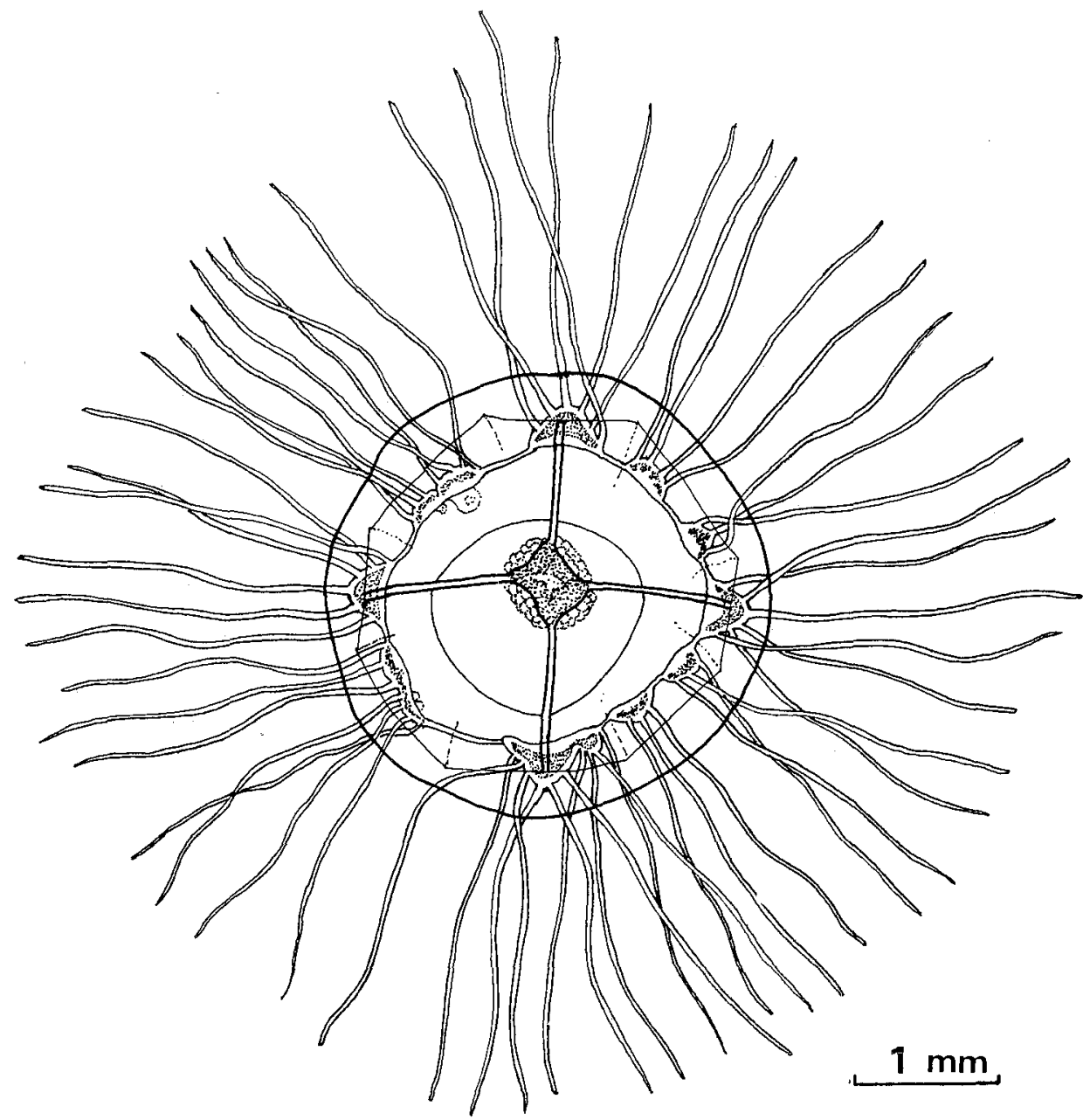

Fig. 5. An extraordinarily grown female medusa reared in the laboratory for 55 days after collection in the sea at Mitsuhama (Aboral view).

month. As a result, various developmental stages ranging from immature medusa with four marginal tentacles to mature one with up to 14 marginal tentacles were collected from April to August (Fig. 6). Not a few medusae were collected in a year $(N=45$ in 1992, $N=22$ in May, 1993), thus the present species was not rare in this locality (Fig. 7, cf. Horita, 1994). Since the immature medusa resembles to the 1-day-old medusa, it appears to have been released from the hydroids from May to July (Fig. 7). It may be mentioned here that in 1991 the immature medusae were collected on April 29. The rising of water temperature, after a drop in winter (February and March are the coldest months), might have triggered the formation of medusa bud of this species (Fig. 7). No medusae were found from September to March during which the water temperature dropped continuously. 


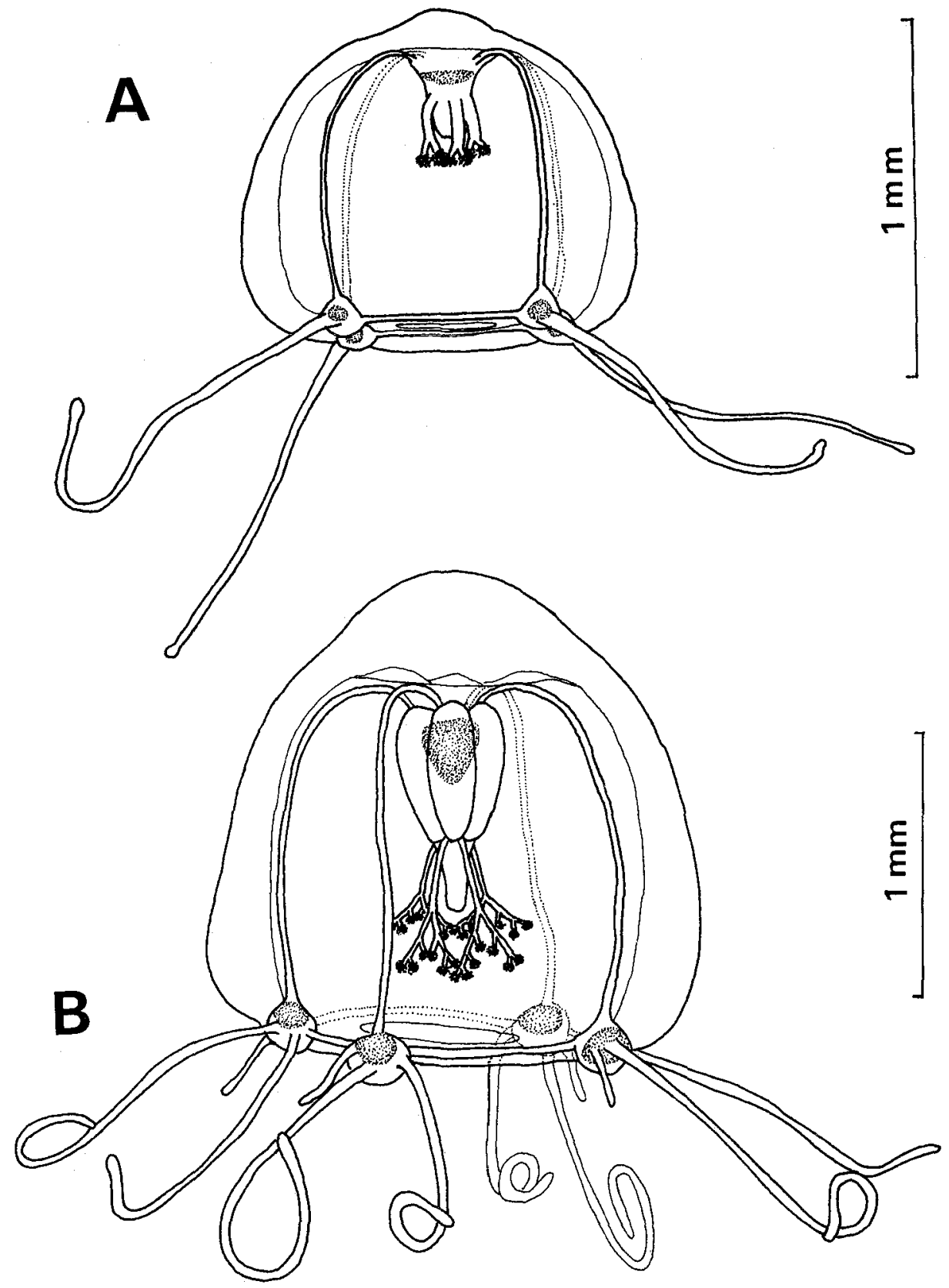

Fig. 6. Medusae of Bougainvillia bitentaculata collected in the sea at Toba.

A: Immature medusa with four marginal tentacles; B: Mature male medusa with 12 marginal tentacles.

The specimens from Toba are divided into several growth forms according to their number of marginal tentacles, sizes, and maturation of gonads (Table 


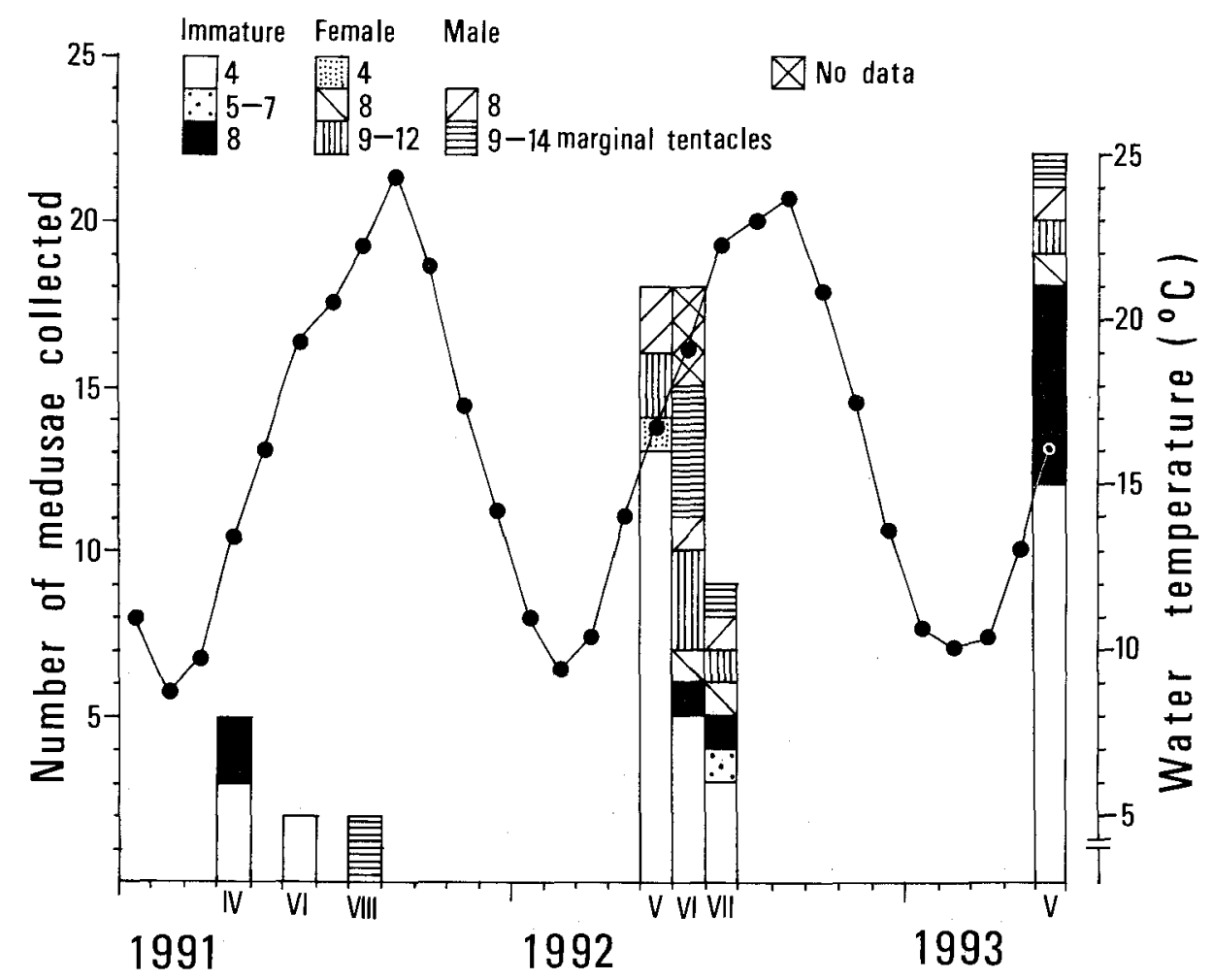

Fig. 7. Seasonal occurrence of medusac of Bougainvillia bitentaculata in the sea at Toba together with monthly change of seawater temperature $5 \mathrm{~m}$ in depth. The temperature was measured three times a day and the monthly average was calculated. Medusac are divided according to the number of marginal tentacles and the maturation of gonads.

6). Generally, as the medusae grow they have more marginal tentacles. Formation of the marginal tentacles of the second set is synchronous since the medusa with 5-7 tentacles is very few in number $(\mathrm{N}=1)$. Formation of the marginal tentacles of the third set is not so synchronous as that of the second set, and the number of medusae with 12 tentacles and that with $9-11$ ones were the same $(N=6)$. All the medusae with more than eight marginal tentacles are mature. One female medusa, which had only four marginal tentacles and four unbranched oral tentacles and was 1.1 $\mathrm{mm}$ in diameter, had a very short peduncle and four gonads containing eggs (Fig. 8). This medusa seems to be nearly mature, but we did not observe its spawning since it was preserved soon after collection.

Frequency distribution of the number of the marginal tentacles in a tentacular bulb was examined in the aforementioned specimens collected in the sea (Table 7), combining with the previous data of Uchida $(1925,1927)$ and Kubota \& Yamada (1982). Most of larger medusae had usually two marginal tentacles in each tentacular bulb as described originally by Uchida (1925). The noticeable presence of three or four marginal tentacles in each tentacular bulb (Fig. 6, B) was also observed. However, 
Table 6. The number of tentacles, umbrellar diameter and maturation of Bougainvillia bitentaculata collected in the sea at Toba.

\begin{tabular}{lll}
$\begin{array}{l}\text { No. of marginal } \\
\text { tentacles }\end{array}$ & $\begin{array}{c}\text { Diameter }(\mathrm{mm}) *: \\
\text { mean } \pm \mathrm{SD}, \\
\text { range }\end{array}$ & $\begin{array}{l}\text { No. of medusae collected } \\
\text { (F: female; M: male; G: with gonads } \\
\text { but sex indeterminable). }\end{array}$ \\
\hline $4(1 \times 4)$ & $0.77 \pm 0.11,0.52-1.10$ & $38(1 \mathrm{~F}+5 \mathrm{G})$ \\
6 & 0.76 & $1(1 \mathrm{G})$ \\
$8(2 \times 4)$ & $1.08 \pm 0.15,0.84-1.44$ & $20(3 \mathrm{~F}+5 \mathrm{M}+6 \mathrm{G})$ \\
9 & 1.32 & $1(1 \mathrm{M})$ \\
10 & $1.64 \pm 0.14,1.54-1.80$ & $3(1 \mathrm{~F}+2 \mathrm{M})$ \\
11 & $1.47 \pm 0.10,1.40-1.54$ & $2(2 \mathrm{~F})$ \\
$12(3 \times 4)$ & $1.47 \pm 0.28,1.04-1.90$ & $6(3 \mathrm{~F}+3 \mathrm{M})$ \\
13 & 1.30 & $1(1 \mathrm{~F})$ \\
14 & 1.60 & $1(1 \mathrm{M})$ \\
\hline
\end{tabular}

* Measured in the preserved specimens.

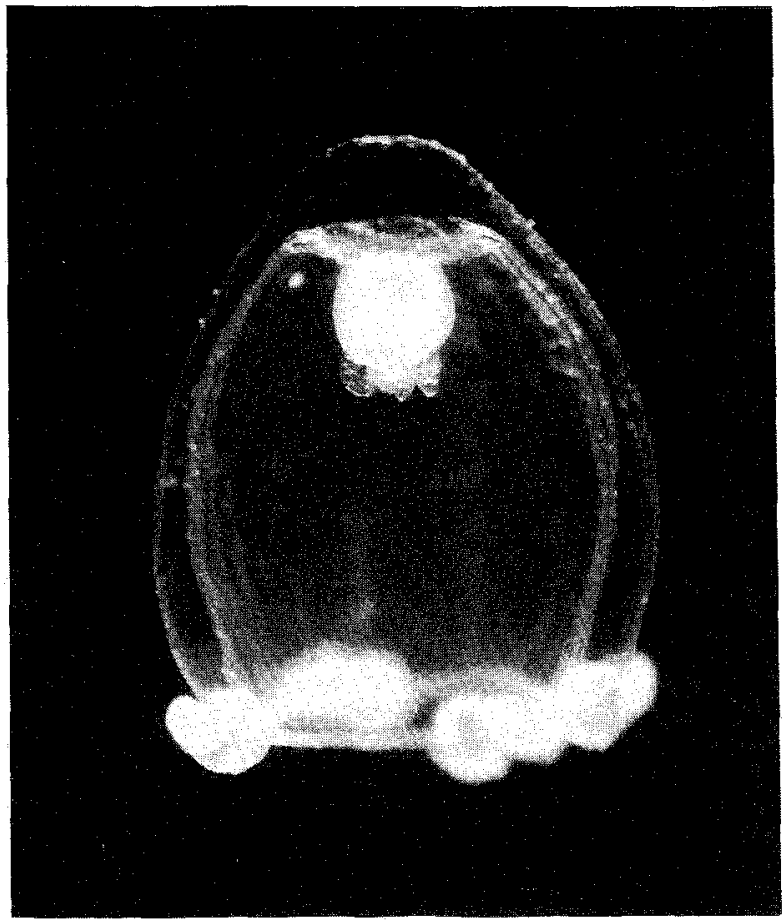

Fig. 8. The smallest female medusa of Bougainvillia bitentaculata collected in the sea at Toba. Note the four marginal tentacles and unbranched four oral tentacles. 
Table 7. Frequency distribution of the number of marginal tentacles per tentacular bulb of medusae of Bougainvillia bitentaculata collected from the sea.

\begin{tabular}{ll}
$\begin{array}{l}\text { No. of marginal tentacles } \\
\text { in each tentacular bulb }\end{array}$ & $\begin{array}{l}\text { Frequency (No. of } \\
\text { tentacular bulbs) }\end{array}$ \\
\hline
\end{tabular}

73 specimens from Toba

$\begin{array}{rr}1 & 154 \\ 2 & 88 \\ 3 & 48 \\ 4 & 2\end{array}$

1 specimen from Mitsuhama

$\begin{array}{ll}2 & 1 \\ 3 & 3\end{array}$

4 specimens from Oshoro (from Kubota \& Yamada, 1982)

$\begin{array}{ll}1 & 7 \\ 2 & 8\end{array}$

1 specimen from Yunohama, Yamagata Pref. (from Uchida, 1925)

2

3 specimens from Seto (=Shirahama), Wakayama Pref. (from Uchida, 1927)

2

these values are smaller than those of the laboratory-reared medusae described above.

\section{Egg Size and Spawning Time}

One female medusa from Mitsuhama was reared at $22^{\circ} \mathrm{C}$ in filtered seawater in $60 \mathrm{ml}$ vessel under alternating $12 \mathrm{~h}$ periods of light and dark. This medusa spawned many eggs 37-40 minutes after dark (observed on three occasions). The unfertilized eggs of this specimen were 86-128 $\mu \mathrm{m}$ in diameter $(106 \pm 10 \mu \mathrm{m}$ in mean $\pm \mathrm{SD}, \mathrm{N}=113$ ) soon after the discharge from the gonads. In a reared specimen from Toba, discharged unfertilized eggs were $88-106 \mu \mathrm{m}$ in diameter $(102 \pm 4.7 \mu \mathrm{m}$ in mean $\pm \mathrm{SD}, \mathrm{N}=13$ ), showing the same egg size as the medusae from Mitsuhama.

\section{Acknowledgments}

We wish to our sincere gratitude to Dr. Tadashige Habe for his invaluable identification of a gastropod. We also wish to express our cordial thanks to Mr. Suekatsu Yagi, Maruko \& Co., Ltd., for providing the data of water temperature in Toba Bay and to Dr. T. V. Raveendran for reading the manuscript. 


\section{References}

Horita, T. 1994. Coelenterata (jellyfish) in Mie Prefecture. In "Organisms in Mie". The Mie Biological Society, Mie, Japan. pp. 312-323. (In Japanese)

Kubota, S. \& Yamada, M. 1982. Metamorphosis of a hydromedusa Bougainvillia bitentaculata Uchida, 1925. Proc. Jpn. Soc. syst. Zool., 24: 13-18.

Uchida, T. 1925. Some hydromedusae from northern Japan. Jpn. J. Zool., 1: 77-100.

- 1927. Studies on Japanese hydromedusae. I. Anthomedusae. J. Fac. Sci. Univ. Tokyo, Sect. IV, Zool., 1: 145-241, pls. 10-11.

Yamazi, I. 1958. Preliminary check-list of plankton organisms found in Tanabe Bay and its environs. Publ. Seto Mar. Biol. Lab., 7: 111-163. 